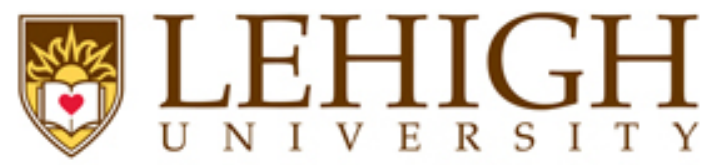

ARIEL
UNIVERSITY
PRESS

Archaeology and Text: A Journal for the Integration of Material Culture with Written Documents in the Ancient Mediterranean and Near East

Vol. 1, 2017 
Archaeology and Text: A Journal for the Integration of Material Culture with Written Documents in the Ancient Mediterranean and Near East

\section{Editors}

David Small, Lehigh University.Email dbs6@lehigh.edu

Itzhaq Shai, Ariel University.Email: shai.itzick@gmail.com 


\section{Editorial Board:}

Yonatan Adler, Department of Land of Israel Studies and Archaeology, Ariel University

Colleen Darnell, Department of Art History, University of Hartford

Thomas Gallant, Department of History, University of California at San Diego

Onno van Nijf, Department of History, University of Groningen

Robin Osborne, Faculty of Classics, Cambridge University

James Whitley, School of History, Archaeology, and Religion, Cardiff University

K. Lawson Younger, Jr., Department of Old Testament and Semitic Languages, Trinity International University 


\section{Table of Contents}

Divination Texts of Maresha - Archeology and Texts

Esther Eshel, Bar Ilan University, Ian Stern, Archaeological Seminars Institute

Toward an "Archaeology of Halakhah": Prospects and Pitfalls of

Reading Early Jewish Ritual Law into the Ancient Material Record

Yontan Adler, Ariel University

27

Purity Observance among Diaspora Jews in the Roman World

Jodi Magness, University of North Carolina at Chapel Hill

Visual Models in Archaeology and Harmonization of Archaeological

and Literary Data Catalin Pavel, Kennesaw State University

Reading Between the Lines: Jewish Mortuary Practices in Text and Archaeology Karen B. Stern, City University of New York, Brooklyn College

Complex Purity: Between Continuity and Diversity in Ancient Judaism 


\section{Editorial Statement}

The study of the human past has conventionally been divided between two distinct academic disciplines depending upon the kind of evidence under investigation: "history", with its focus on written records, and "archaeology", which analyzes the remains of material culture. This new annual publication, Archaeology and Text: A Journal for the Integration of Material Culture with Written Documents in the Ancient Mediterranean and Near East, aims to bridge this disciplinary divide by providing an international forum for scholarly discussions which integrate the studies of material culture with written documents. Interdisciplinary by nature, the journal offers a platform for professional historians and archaeologists alike to critically investigate points of confluence and divergence between the textual and the artifactual.

We seek contributions from scholars working in the ancient Mediterranean and Near East. Contributions with a theoretical or methodological focus on the interface between archaeology and text are especially encouraged. By publishing all of its articles online, the Archaeology and Text seeks to disseminate its published papers immediately after peer-review and editorial processes have been completed, providing timely publication and convenient access.

In providing a forum, we will publish reviews of recent publications which deal with the issue of archaeology and text. When appropriate, each volume will include a short overview of recent conferences which have treated this topic as well. 


\section{Recent Conferences focused on the Issue of Archaeology and Texts}

Archaeology and Text: Toward Establishing a Meaningful Dialogue between Written Sources and Material Finds

Conference held on Sunday May 10 - Monday May 11, 2015. Sponsored by Ariel University and the Israel Ministry of Science, Technology, and Space. Conference was organized into several small sessions. Papers ranged from those dealing with the issue of archaeology and texts in the Near East to those focusing on this issue in Mediterranean Studies. Topics ranged from the application of textual material to singular sites - Text and Archaeology: the Case of Tel Rehov in the 10-9 $9^{\text {th }}$ Centuries BCE, A. Mazar - to more theoretical contributions - Purity and Purification in the Dead Sea Scrolls and the Mikva'ot of Qumran: the Convergence of Archaeology and Text, L. Schiffman.

Textual Archaeology of Ancient Near East: Are We Doing it Wrong?

Conference held on Thursday December 10 - Sunday December 13, 2015. Sponsored by the McDonald Institute for Archaeological Research, Cambridge University. Conference was subdivided into various sessions with invited responses. Topics focused on issues pertaining to the Near East with a few inclusions of cases dealing with the Bronze Age Aegean. Papers ranged from those treating the issues of the uses of archaeology and texts in broad areas in the Near East, such as Assyriology - Of Haematite and Apricots: Matching up the Mesopotamian World, N. Postgate - to contributions touching upon landscape - Satellite Remote Sensing, Archaeological Survey, and Historical Geography in Northern Mesopotamia, J. Casana - the analysis of texts in ancient Mayan studies - Histories of Decline and Fall: Archaeology, Epigraphy, and the Maya Collapse, N. Carter.

The Conference is being published by the McDonald Institute, with its organizer, Y. Heffron as the editor. 


\title{
Divination Texts of Maresha - Archeology and Texts
}

\author{
Esther Eshel, Bar Ilan University \\ Ian Stern, Archaeological Seminars Institute
}

\begin{abstract}
The discovery of over 384 Aramaic ostraca in Subterranean Complex 169 of Maresha includes, to date, 137 ostraca that can be categorized as divination texts. We believe they were possibly utilized for cultic purposes. In this same subterranean complex a disproportionate number of other finds were uncovered that can be considered cultic in nature. These include astragals, aniconic kernos lamps, figurines, small domestic stone altars and models of chalk phalli. This article is a preliminary look at some of the various genres of Aramaic inscriptions in this Subterranean Complex 169, their possible origins and parallels in the ancient Near East, as well as their possible connection to the many cultic items discovered with them.
\end{abstract}

\section{Introduction}

During the course of our excavations of Subterranean Complex 169 (hereby SC 169), located in the lower city of Maresha, a significant number of finds that can be categorized as "cultic items" were uncovered. These items include astragals (knucklebones), aniconic kernos lamps, models of chalk phalli, figurines, and small domestic stone altars. Significant portions of the epigraphic material we have also discovered in this complex appear to be cultic in nature as well and, more specifically, used for purposes of divination. This article will discuss what connection can be found, if any, between these cultic items and Aramaic divination.

\section{The Site of Maresha}

There are a number of biblical and post biblical references to Maresha (Fig. 1) as a city in ancient Judah (Josh 15:44, II Chr 2:7-9, and Mic 1:13-15, Josephus, Ant 8.10.1 §246, Eusebius, Onomasticon 130:10-12). The archaeological record clearly reflects an Iron Age II presence (Bliss and Macalister 1902: 58, Kloner 2003: 9-16). Following the 


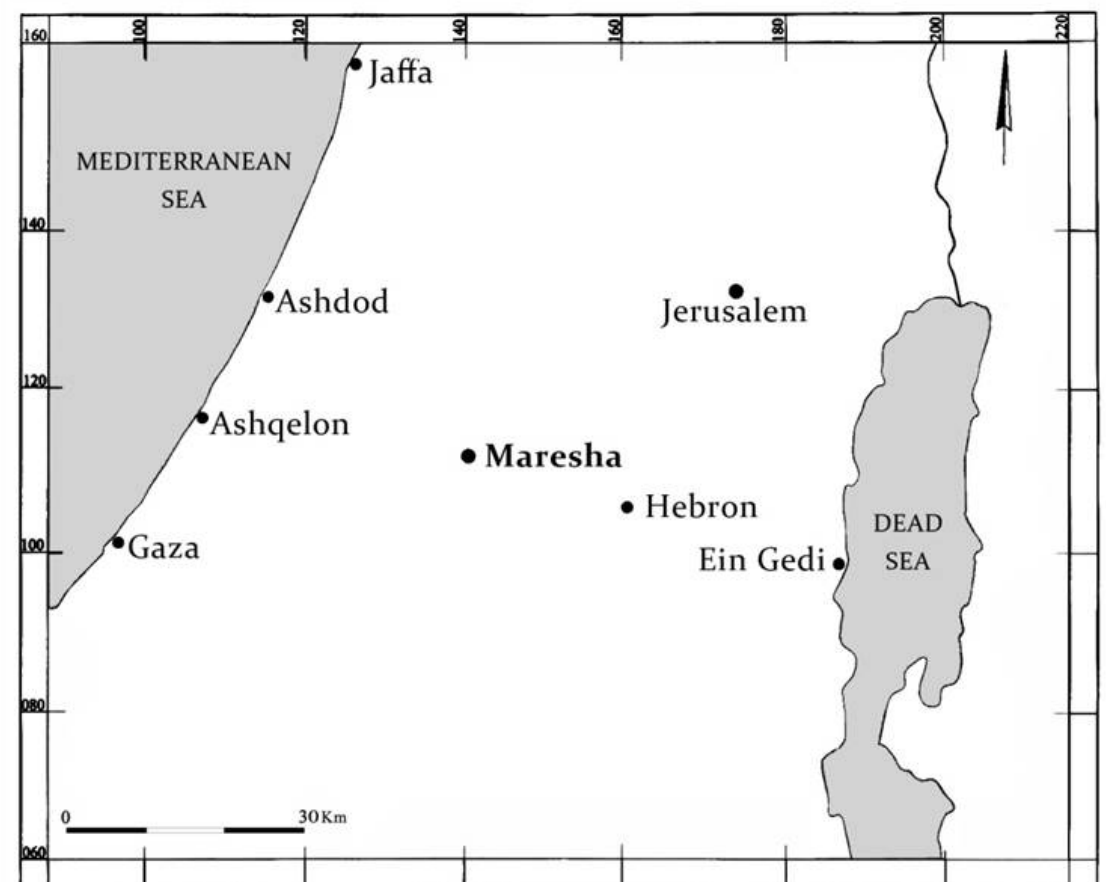

Fig. 1 - Map of Israel with Maresha

Babylonian conquest of Judah in 586 B.C.E. and the subsequent conquest of Edom by Nabonidus in 552 B.C.E., there was a migration of Edomites and other ethnic groups into Southern Judah. While there is little archaeological evidence from the sixth-fifth centuries, material finds from the fourth century B.C.E. have been discovered (Eshel 2010: 38, Lemaire 1996: 84-85). Nevertheless, the status of Maresha during the Persian period is unclear. By the third century B.C.E., a Hellenized Sidonian community had settled in Maresha (Peters and Thiersch 1905: 36-39). The city's close commercial ties with the Ptolemies during the third century B.C.E. is evident in the Zenon Papyri (P. Cairo 59006, 59015, 58537). In ca. 198 B.C.E. the city came under Seleucid control and the process of Hellenization intensified. Later, during the Hasmonean wars, Maresha was used as a base for attacks against Judea and subsequently suffered retaliation from the Maccabees (2 Macc 12:35). Following the conquest by John Hyrcanus in 107 B.C.E., the city was abandoned or transferred to a different location. ${ }^{1}$

Maresha was first excavated in 1900 by Bliss and Macalister, who uncovered a planned and fortified Hellenistic city encircled by a town wall with towers. Large-scale excavations of surface areas and some of the subterranean complexes were directed by Amos Kloner, under the auspices of the Israel Antiquity Authorities, from 1989 to 2000. The results of the rich finds were published in three volumes (Kloner 2003, Ehrlich and Kloner 2008, Kloner 2011), and more are being prepared.

\footnotetext{
${ }^{1}$ While Josephus, in Ant 14.4.4 $§ 75$, JW 1.7.7 §156, attests to a post Hyrcanus Maresha, no archaeological evidence of such a city has been found to date aside from a number of surface coins.
} 


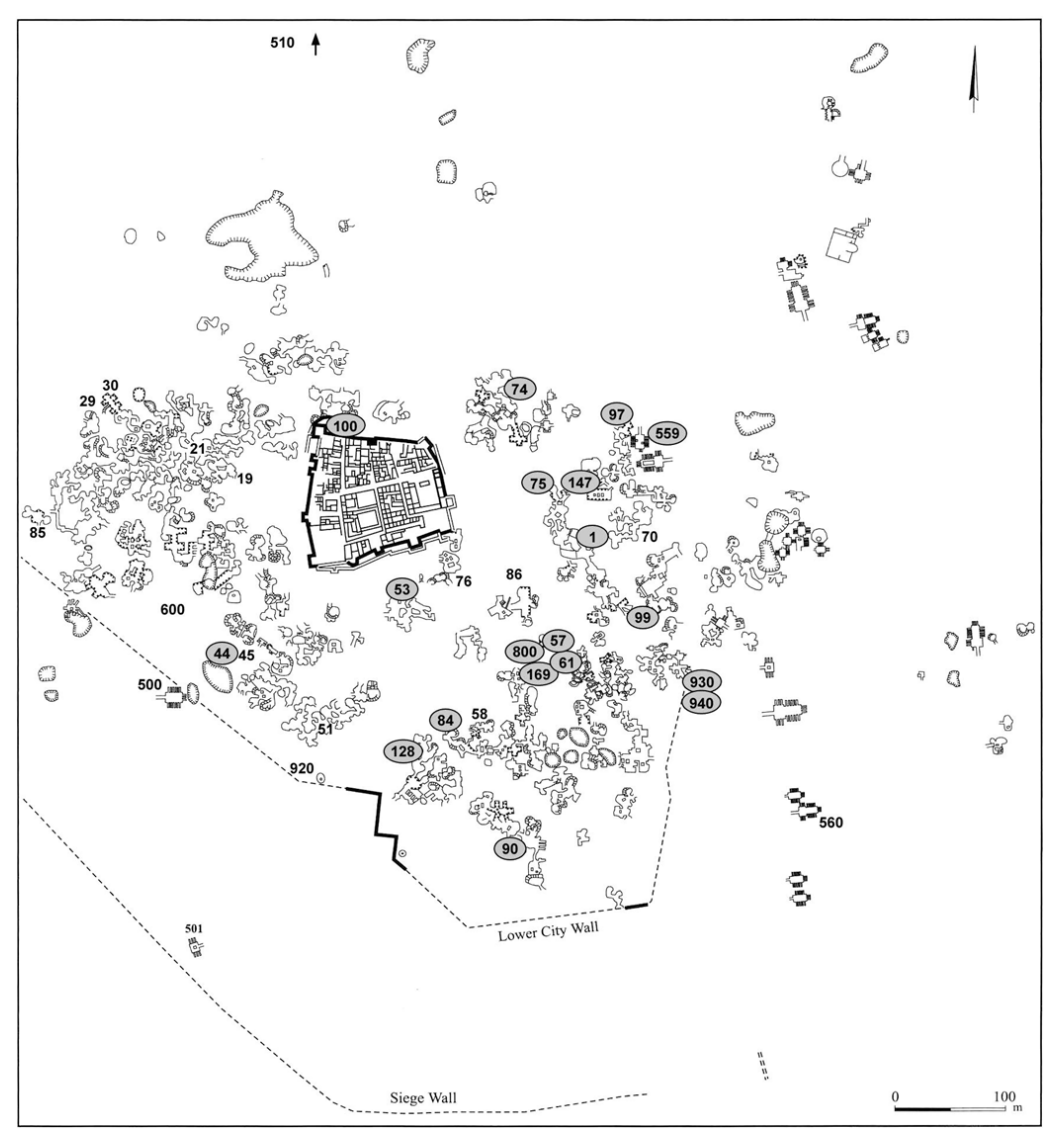

Fig. 2 - Plan of Maresha with SC 169, 57, 800

Beginning in 2000, an archaeological excavation was conducted in SC 169, located in the lower city of Maresha (Fig. 2), approximately 105 meters from the upper city of Maresha in what is one of the most unusual and interesting complexes in the Maresha area. It contains 13 rooms that are still being excavated. The excavation, on behalf of the Israel Antiquities Authority, Hebrew Union College, and the Archaeological Seminars Institute, was directed by Ian Stern and Bernie Alpert (Stern and Alpert 2014).

\section{The Cultic Items}

During the course of the excavations of SC 169, a significant number of finds that can be categorized as "cultic items" were uncovered. Most of these finds are from subterranean complexes that contain anthropogenic debris dumped inside during the Hellenistic period from surface dwellings and that therefore, unfortunately, lack a clear stratigraphic context. Nevertheless, the finds in these "dumps" can still be dated typologically. They range chronologically from the fourth to the late second centuries B.C.E.. These include astragals (knucklebones), aniconic kernos lamps, and models of chalk phalli. 
Astragals - Fifty astragals (Fig. 3) or knucklebones were discovered in SC 169; six are inscribed with Greek letters, of which one is made of glass (Fig. 4) and one of lead. These astragals represent $44 \%$ of the sheep/goat bones discovered in SC 169, the highest percentage of any excavated subterranean cave system at Maresha (Perry forthcoming). Astragals were used as gaming pieces and for divination during this period. They may have been used for cleromancy or divination by lots. The four sides bearing a name or number and the different combination of numbers can be interpreted as having particular significance for the enquirer. A collection of astragals found in

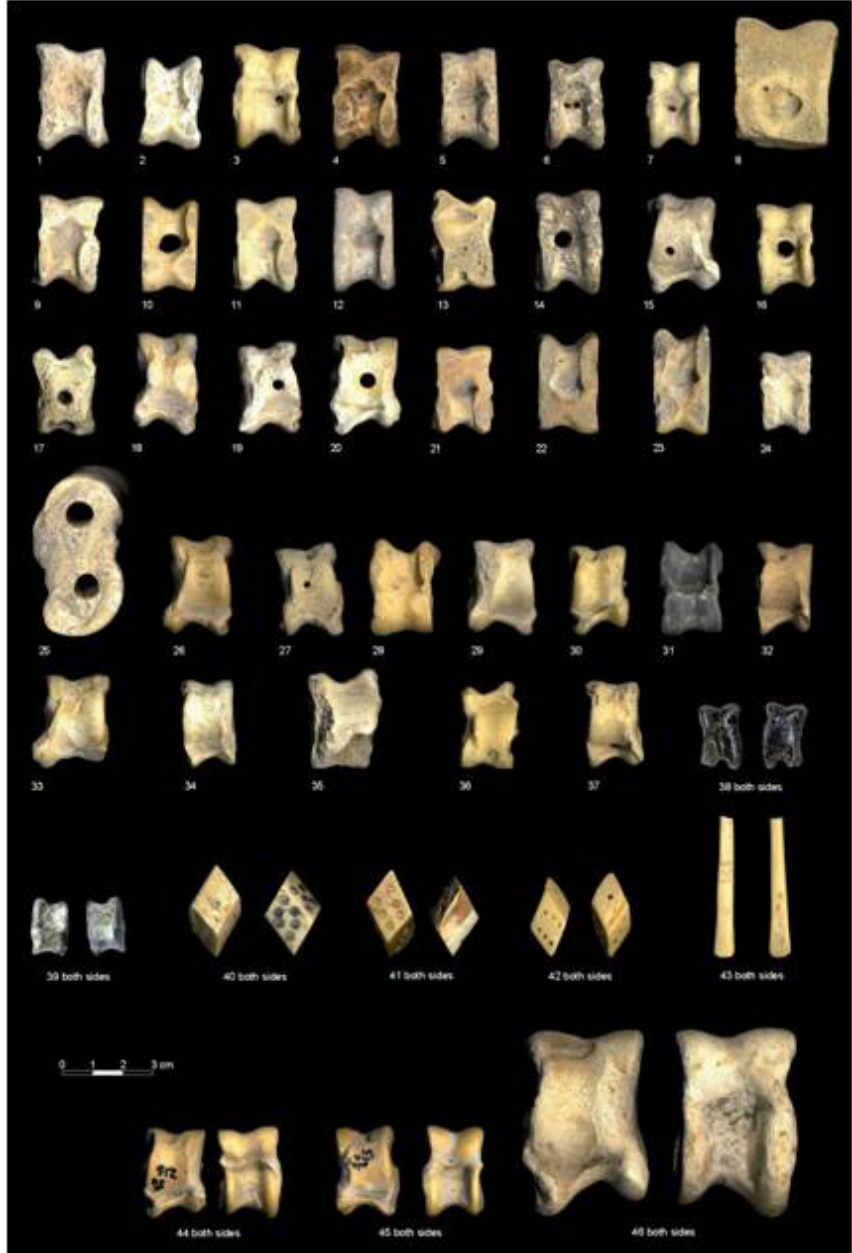

Fig. 3 - Astragals from SC 169 Branchidai-Didyma in western Anatolia might serve as a useful parallel. Alan Greaves (2012: 177-206) assessed the evidence for different aspects of the divinatory process used there, including divination by mantic trance

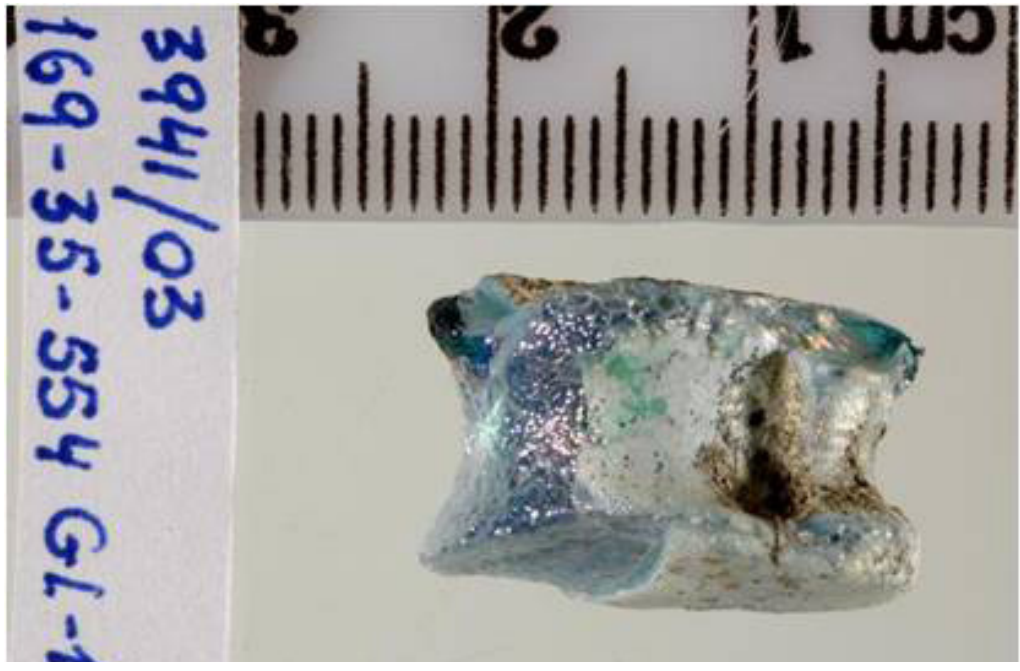

Fig. 4 - Glass Astragal from SC 169 and cleromancy.

This included the use of astragals as a means of delivering responses. According to Greaves, the three criteria that point to divination are: 1 . context, 2 . their modification 
or production in other materials, and 3. inscriptions. Our astragals appear to meet these criteria.

\section{Aniconic kernos}

lamps - The discovery of hundreds of aniconic kernos lamps attached to stands is unique to Maresha (Figs. 5-6). The kernos vessels on which the lamps were

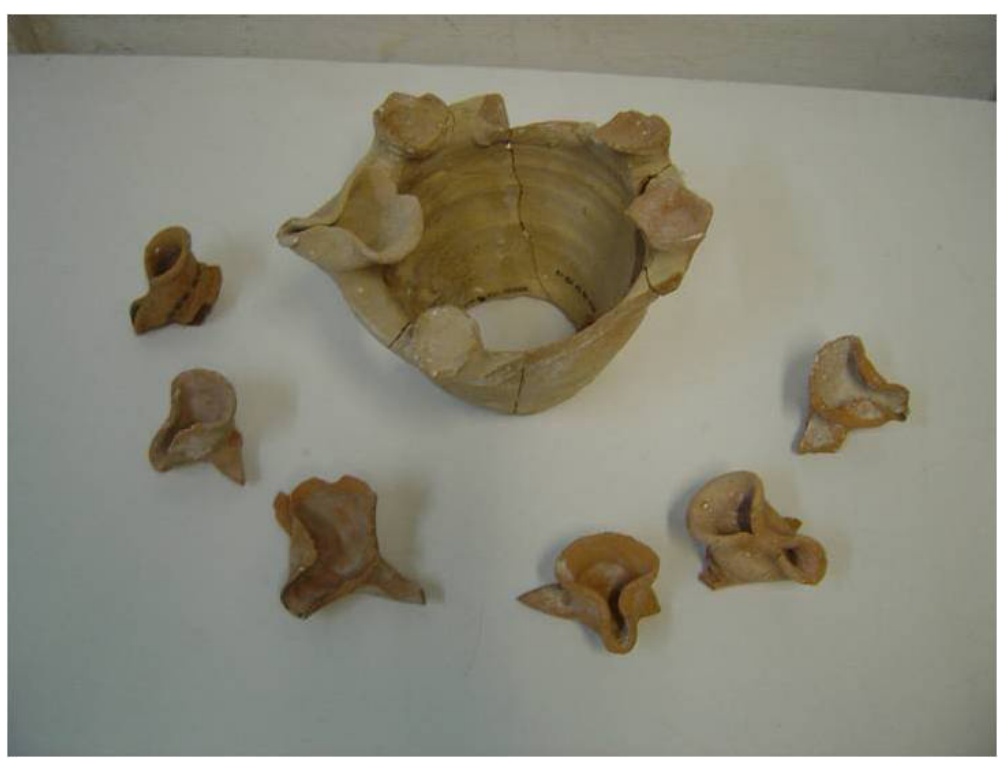

Fig. 5 - Kernoi from SC 169 mounted are among the most singular artifacts produced in Maresha. It seems that the concept of these vessels was imported from abroad and adapted to local needs and rituals performed at this site (AmbarArmon, Kloner, and Stern 2010: 103140). Of the 763 whole Hellenistic period lamps discovered in SC 169, approximately $42 \%$ are kernos lamps. Kernos vessels, to which small bowls were attached, have been unearthed in large quantities in at least two sites in Greece: Eleusis (Mylonas 1961: 222) and the Eleusinion (Pollitt 1979) in central Athens (Ambar-Armon, Kloner and Stern 2010: 125). Various types of kernos vessels, some of which were local, have also been discovered in Egypt, and some are similar to

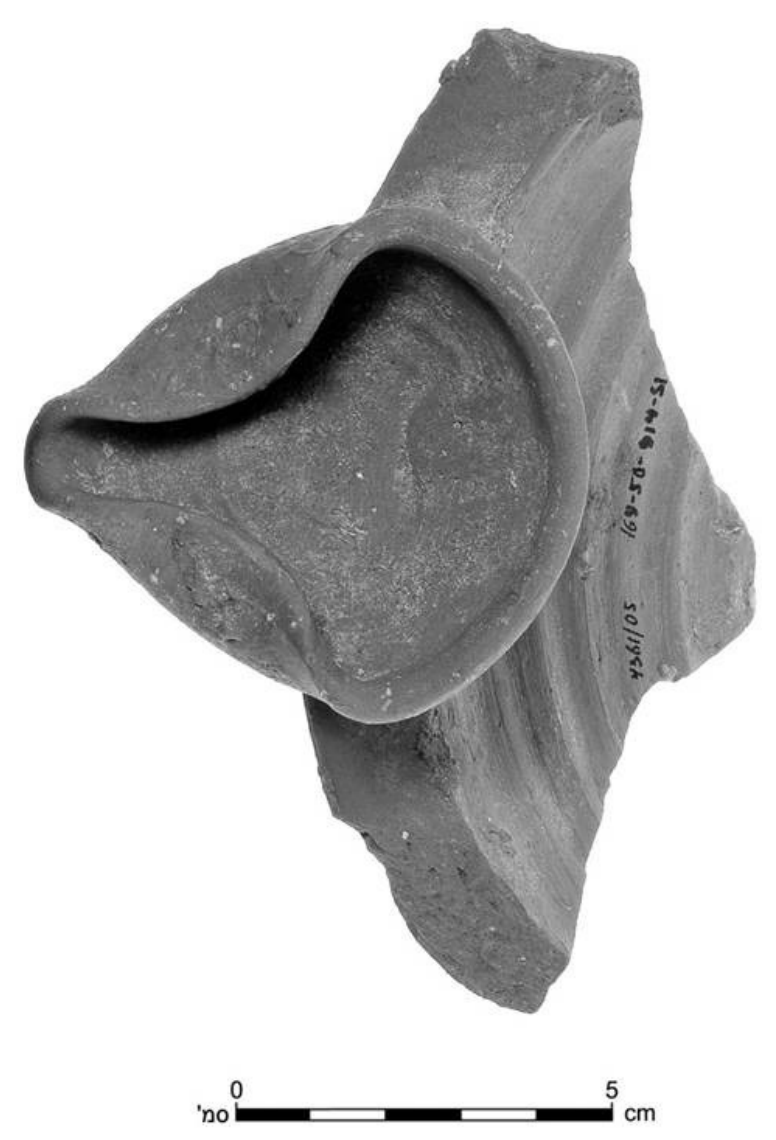

Fig. 6 - Kernos lamp from SC 169 the types found in Athens and Eleusis. The vessels found in Maresha were probably influenced by the nearby Hellenistic center in Alexandria. Ambar-Armon's study 
has shown that the lamps from Egypt had a strong influence on the Maresha lamps (Ambar-Armon 2007: 304-6), and suggests that, by extension, also the kernos lamps felt this influence. Lamps attached to vessels have been found in ritual contexts in the Hellenistic world. It is acknowledged that they were used in temple rituals and were designed accordingly: for example, such lamps in the Temple of Athena in Corinth (Broneer 1930: 34, fig. 16:133 no. 42), in Naucratis in the Temple of Aphrodite (Bailey 1975: 96, Q152), and in Knidos in the Temple of Demeter (Bailey 1988: 342, Q2742).

The vessels mentioned by Athenaios of Naucratis, author of Deipnosophistae (Pollitt 1979: 205), were associated with the mystery rites in Eleusis in Attica. This secret ritual was one of the most widespread secret rituals of the ancient world, promising participants a special place in the afterlife. The content of the ceremonies remain a secret until the present. It is believed that the priests who took part in this procession carried kernos vessels on their heads. Evidence of this has been found in a vessel decorated with figures carrying kernos vessels on their heads (Cintas 1950: pl. 46). However, most of the vessels from Maresha were large and heavy, and it is more likely that they were placed on flat surfaces.

Finally, Ambar (Ambar-Armon, Kloner, and Stern 2010: 132-3) found a lack of soot marks on $41 \%$ of the lamp nozzles (as opposed to only $4 \%$ of all the lamps at Maresha) and $27 \%$ showed limited use, shown by slight traces of soot (as opposed to $2 \%$ of the closed lamps). In addition, the oil reservoirs in the lamps had a limited capacity, meaning a short burning time (ca. 1 hour - as tested by personal observation). All of this suggests that the main function of these kernoi was something other than merely illumination.

Circumcised phalli-To date, we have discovered twenty models of circumcised phalli (Stern 2012: 57-88), carved from local chalk, in several of the subterranean complexes (Figs. 7-8). They appear to be erect, partially broken, and life size. Sixteen of the 20 phalli discovered at Maresha were found in SC

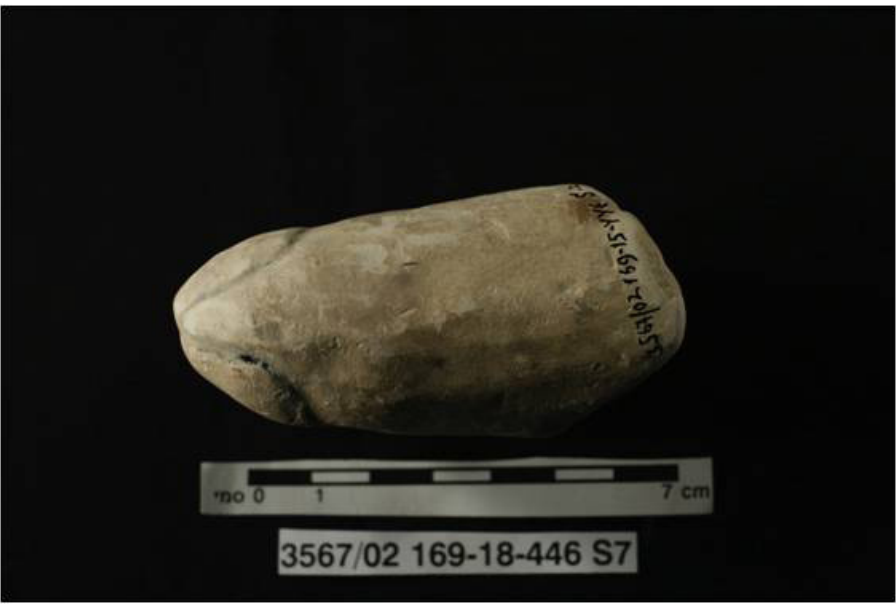

Fig. 7 - Phallus from SC 169 169. While Roebuck (1951: 
117-118) believes that flaccid phalli were utilized as votive genitals in a healing cult, Ehrlich (2009: 18-20) argues that they are connected to the cult of Dionysus and Hermes and had an apotropaic value. It is possible that they were used in a fertility rite.

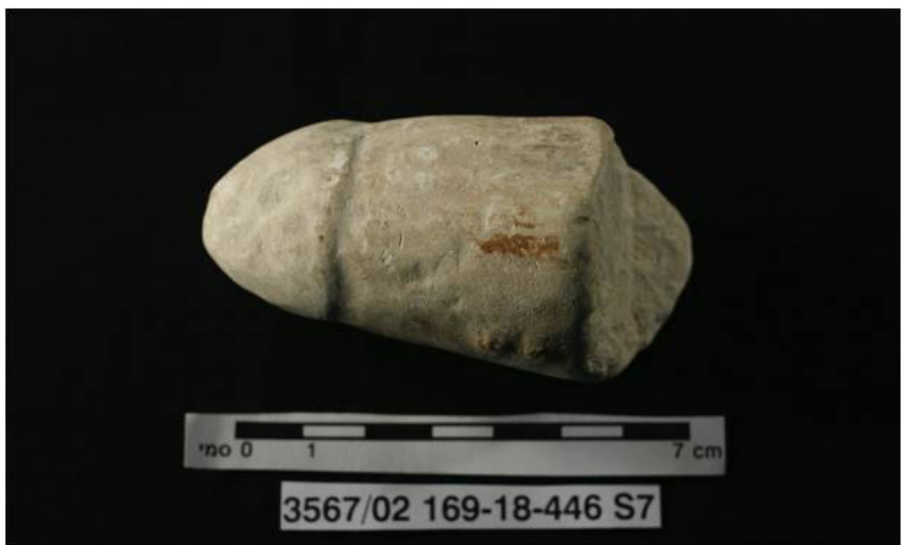

Domestic Altars - Finally, over 40 small domestic stone altars were found in SC 169 (Figs. 9-10).

The concentration of these cultic items in one subterranean complex raises certain questions. Parallels in other parts of the Hellenistic world indicate that such items had a ritualistic purpose.

\section{The Heliodorus Stele and the Temple}

Approximately 30 meters from SC 169 is Area 800, which has been identified as a shrine by both Kloner (2001: 111-112) and Graicer (2012: 183-193). The structure, constructed on an east west axis, is the largest building to be found in Maresha to date, measuring ca. $13 \times 27$ meters, with remains of 3-4 layers of

Fig. 8 - Phallus, other side from SC 169

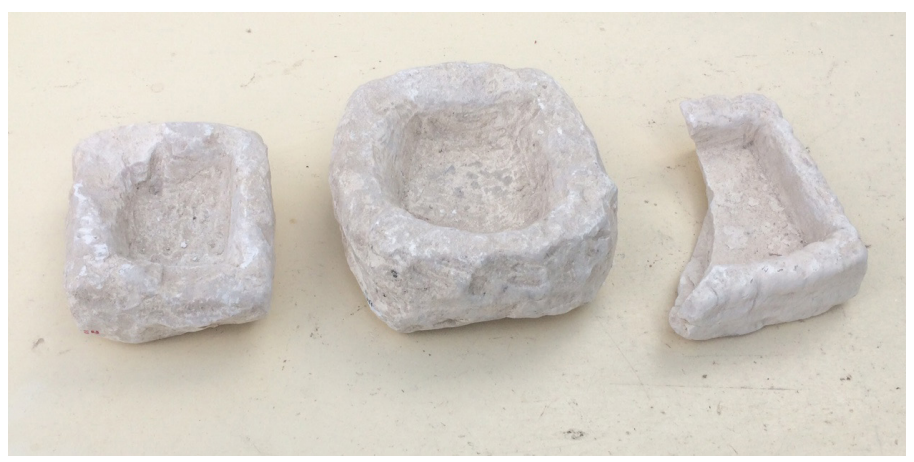

Fig. 9 - Small domestic altars from SC 169

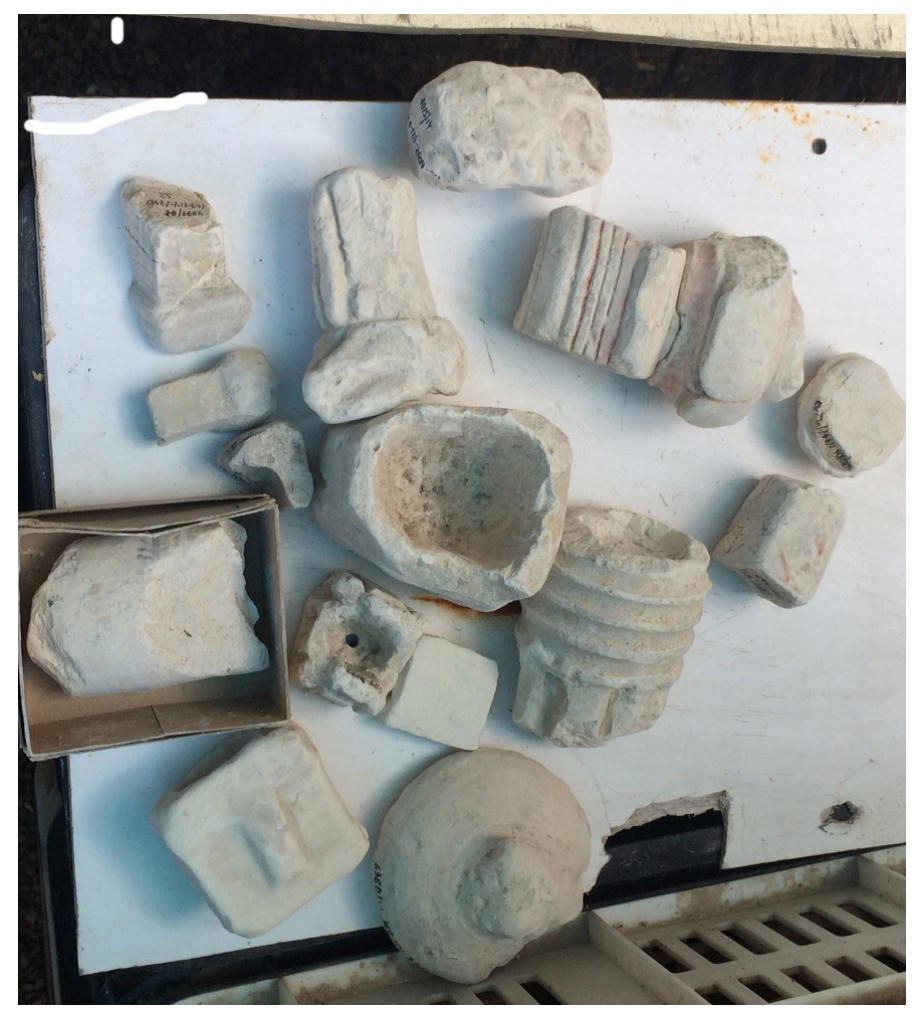

Fig. 10 - Small domestic altars from SC 169 
large, nari stone walls. Graicer believes that it was constructed by Ptolemy IV after his victory at the battle of Rafiah, in honor of his wife Arsinoe III.

Complex 169 is only ca. 10 meters from SC 57, where the famous "Heliodorus" stele was discovered. ${ }^{2}$ It concerns the Seleucid king Seleucus IV's appointment of a certain Olympiodoros to a position of religious responsibility in Koile Syria and Phoenicia. The importance of the location of this SC and, more specifically, its proximity to these other two sites, will be made clear as we proceed. The consensus of scholarly opinion is that the "Heliodorus Stele" once stood near or inside a temple (Gera 2009).

\section{Divination}

Divination was a common way of predicting the future in the ancient world. The diviners would investigate different naturally-occurring phenomena, interpreted as signs, which bear a hidden meaning in predicting the future. Another way for the diviners to access such information was by creating predictions from shapes regarded as omens. The ritual of conceiving omens from the characteristics of sheep livers spread from Babylonia and reached Etruria, where it was performed in a very similar way. According to classical literature, the Greeks also used liver omens, as well as divination by pouring oil or flour onto liquid (Luck 1985: 229-305).

The Israelites were also familiar with the divination practices that were common in the surrounding countries. Ezek 21:26 describes the king of Babel consulting

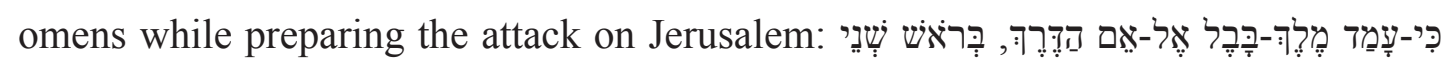
"For the king of Babylon has stood at the fork of the road, where two roads branch off, to perform divination: $\mathrm{He}$ has shaken arrows, consulted teraphim, and inspected the liver". Another reference to the Babylonians using celestial divination is mentioned in Isa 47:13

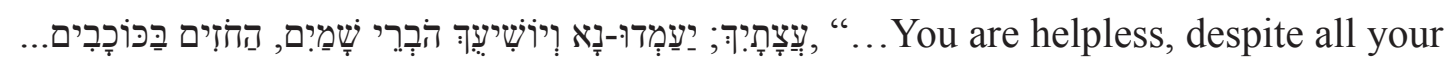
art. Let them stand up and help you now, the scanners of heaven, the star-gazers..."

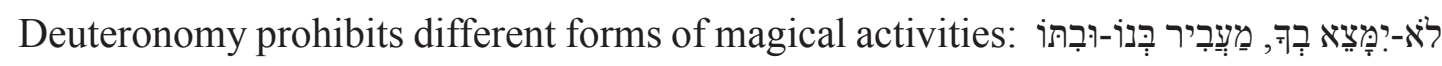
, "Let no one be found among you who consigns his son or daughter to the fire, or who is an augur, a soothsayer, a diviner, a sorcerer, one who casts spells, or one who consults ghosts or familiar spirits, or one who inquires of the dead" (18:10-11).

\footnotetext{
${ }^{2}$ In 2007 Hannah Cotton and Michael Würrle published the first fragments (A+B) of an inscription, found in a private collection. In 2009 three more fragments (C, D, E) of the same inscription found in Maresha were published. For the preliminary report see Stern 2009: 60-61 The inscription was studied by D. Gera 2009: 125-155 and 2009: 100-104.
} 


\section{The Inscriptions}

The excavations at Maresha have yielded more than 1200 Greek and Semitic inscriptions. The majority of the ostraca were written in Greek and can be dated to the Hellenistic period. Of the 480 Aramaic ostraca so far discovered at Maresha, 384 are from Subterranean Complex 169. Included in this collection are a group of 137 Aramaic ostraca, dating to the third - second centuries B.C.E., that share a common formula of

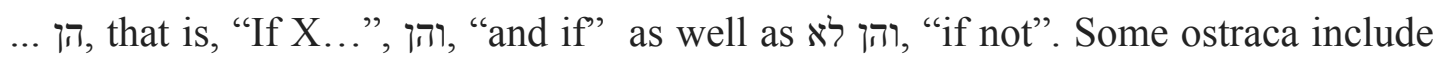
the words: "הן מן אלהין, "Thus, it is from the gods". ${ }^{3}$ Only a few of these inscriptions are complete or almost complete; the rest are fragmentary. The pottery sherds used by the scribes were not always the most suitable writing media - at least one inscription was written on the upper part of a jar, including the rim; in another case the letters were inscribed on a fragment of a bowl, including over the black stripe decorating its upper part. In some instances, several inscriptions were written in scattered different columns on one almost complete bowl (Fig. 11).

The texts from Maresha have not been fully deciphered,

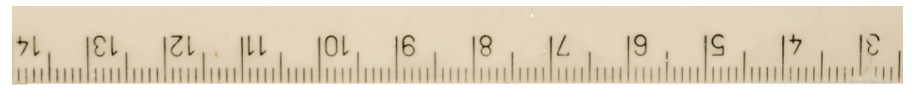
and for a long time we could not identify any specific deity or personal name. Although the ethnicity of the owners of these inscriptions is unknown, previous studies of the ostraca from Idumea have shown that the vast majority were not Jews. The epigraphic material represents a very mixed

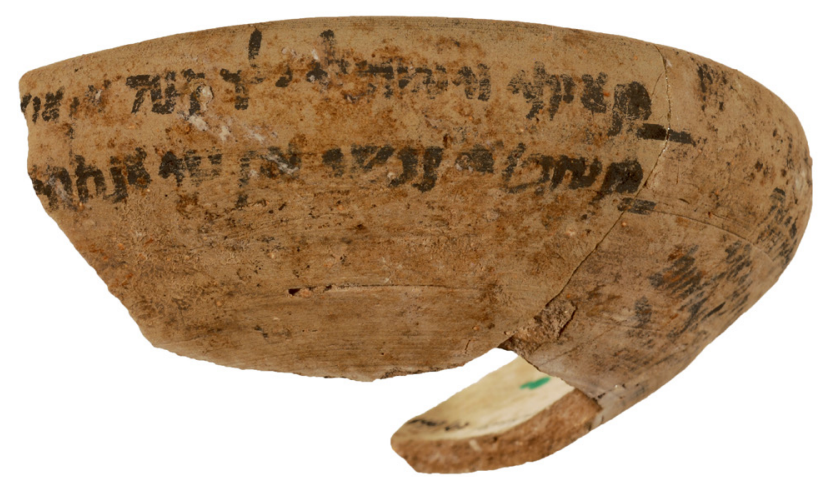

Fig. 11 - Inscribed bowl ethnic population within late Persian-period Idumea, consisting of (31\%) Arabs, (24\%) Idumeans, (28\%) Western Semitic, (9\%) Judahite, (5\%) Phoenician, and (3\%) others (Stern 2007: 213). We have deciphered the name pithin six of the divination תקלתא הן : מן קוס, which tentatively might be translated as: "Thus, the stumbling is from (or: caused by) Qōs" (Reg. No. 169-68-1316-S3). It should be noted, that the theophoric element of Qōs in Edomite personal names is known since the eight century B.C.E.. He was probably the principal god of Edom, as noted by Bartlett (1989: 203), and the

\footnotetext{
${ }^{3}$ The first readings of some of these ostraca were done together with Rivka Elitzur-Leiman, while many are still to be read and fully deciphered.
} 
only deity mentioned in the inscription at Kirbet et-Tannur, dated to the first century B.C.E. (McKenzie and Reyes 2013: 191-192). The worship of Qōs by the Nabateans is documented as late as the second or third centuries C.E. from inscriptions found in Bosra and Jerash (for a summary of the finds and discussion, see McKenzie and Reyes, ibid.).

The first such inscription including the הi formula was discovered by Amos Kloner in Area 61 at Maresha. It was written on a bowl, together with two other inscriptions - a recording of a daily harvest and an account. Lacking Semitic parallels, we interpreted these inscriptions as general scribal exercises, while the inscription was interpreted as a wisdom text, based on parallels found in Ben Sira and the words of Ahiqar (Eshel, Puech, and Kloner 2007: 41-47).

Currently, we have managed to identify 137 texts containing the conditional structure of .... הן The contents of the Mareshap of texts is diverse. They include various genres to be discussed below, whose exact breakdown remains to be determined. Based on the phrase "it is from the gods/Qōs", along with the characteristic structure ... הi, "if X", the ostraca under discussion here may be understood as divination texts (see above). In order to affirm this interpretation, the best analogy is from the Mesopotamian world, where the most common written attestations for divination are conditional omens (see Rutz 2013: 219-221). The Mesopotamian omen was a pair of elements - protasis and apodosis, which together constituted one casuistic statement, usually beginning with the Akkadian word Šumma, "if" (Rochberg 2010). While in the Mesopotamian omens the structure is clear, i.e., the protasis and the apodosis are usually complete - the meaning of the Maresha texts is much vaguer, and no exact parallel with the Mesopotamian omen was found.

In some cases, parallels were found to the Mesopotamian omen texts, especially to the series called Šumma Alu. This is a group of 107 tablets, containing nearly 10,000 private omens dealing with the fate of individuals, associated with unprovoked or uninduced omens and signs. The Šumma Alu omens were developed in Mesopotamia, primarily in Assyria, over the course of several hundred years, and were standardized around the middle of the seventh century B.C.E. (for a general survey of the Šumma Alu texts see: Freedman 1998: 1-14).

והן מותא והן מחלה:In one ostraca (Reg. No. 169-94-1481-S1) we found the phrases , "And if death and if illness", or הן מחלה נשוה-if an illness is put [upon X]" (Reg. No. 169-94-1481-S1), which seems to be the equivalent of the apodosis in many omens from the Šumma Alu group, predicting the bad fate of an individual. For example, "If fungus is seen on a south wall, the mistress of the house will die" (Freedman 1998, Tab. 12: 29). 
The fragmentary phrase [...] הן תפתח תרעא, "if a gate will be opened” (Reg. No. 169114-1700-S2), may be compared to a series of omens which deals with the direction of a house's doorways: "If a house's doorways open towards the south, the inhabitant of that house will be happy; If a house's doorways open towards the north, the inhabitant of that house will not be happy" (Freedman, 1998: 95, Tab. 5:71-72):

In another ostracon already published, Eshel (2011: 181-186) suggested the reading: 1. 1 2. 2. ושתקו והן אותוקא] בללית

"If you are hurt by Lilith [or: if you meet Lilith], And (by) ŠTQW, and if (you are hurt by) 'WTWQ' [...]" (Reg. No. 169-94-1392-S1). Another text reads: [...] והן רוחא, "and if a spirit [...]".

Here we have two or three names of demons. The first is the well-known female demon - לילית (Lillith), followed by what seem to be two additional demons. Starting with אותוקא, this noun should be compared to the Akkadian evil demon utukku(m) (Black, George, and Postgate 2000: 430b).

The second noun שתקו seems to be related to the root שתק, meaning "to be silent," which is used in Aramaic in both the conjugation pa'el, "to silence", and itpa'el, "to be silent". The Maresha ostracon can be explained as referring to a demon whose power is to render people mute or paralyzed. The term can be compared to the name, written on an amulet found in the Cairo Genizah (T.-S. AS 142.12 line 36; cf. Schäfer and Shaked 1994: 85). Here, too, we find parallels in the Šumma Alu texts, ${ }^{4}$ where a series of omens in Tablet 19 deal with different demons appearing in a man's house (Freedman 1998).

הן מן :

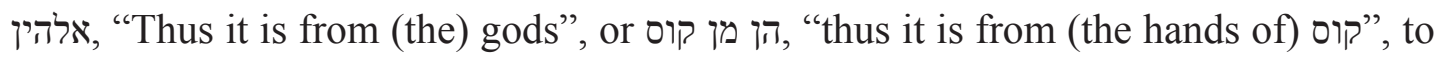

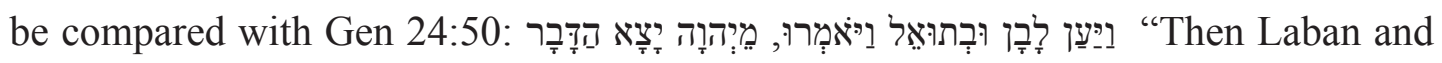
Bethuel answered, 'The matter was decreed by the LORD' ". Another possible link can be made between the phrase הן מן אלהין and tablets from the Šrmma Alu group, in which some omens are understood as "the hand of" different gods. For example: "If a donkey goes out of a man's house - hand of Adad; the property of the owner of the house ... will be substantial" (Tab. 43, line 18); or: "If a prince is riding a chariot and falls to the right of the chariot—hand of Šamaš; trouble" (Line 23). Or in general: "If a big cat cries out in a man's house- - hand of his god; losses will go out of the man's house" (Tab. 45, line 67).

In addition to the demons mentioned in the Maresha texts, the texts seem to

\footnotetext{
${ }^{4}$ For a general survey of the Šumma Alu texts see: Freedman 1998: 1-14.
} 
include other related terms which come from the world of sorcery. Such is the case with the opening word in one of the largest and fully preserved texts - ענוני. The root עננ in Aramaic means: "to practice sorcery". The same is true in Hebrew - the noun עונן usually comes in a group of other magic professionals, as cited previously from Deuteronomy 18: מעונן "a diviner." Interestingly, עונן is sometimes defined in the

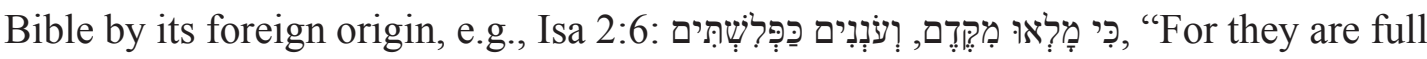
[of practices] from the East, and of soothsaying like the Philistines". An interesting, though unfortunately broken, text from Qumran, 4Q513 (=4QOrdinances $\left.{ }^{\mathrm{b}}\right)$, might shed some light on the discussed ostraca from Maresha, as it also mentions [...] עשני[,

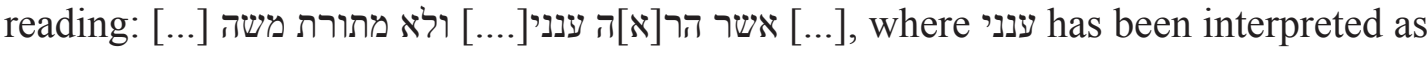
either a personal name (Wacholder 2001) or, better, as translated first by Baillet, "that he showed omens [...] and not from the Law of Moses" (1982: 290). Qimron corrected the reading, reconstructing: (2013: 199). He accepted Baillet's interpretation of עני as derived from מעונן, "one who creates illusions" (see b. Sanhedrin 65 b), here in 4Q513 referring to the Pharisaic leaders.

Another genre found in these ostraca, is the terminology related to astrology. For example, the usage of the noun מחשא can be found in another mentioned ostracon (Fig. 12; Eshel 2011: 181-186). Eshel suggests interpreting this as an illuminated phenomenon produced by stars or meteors. Further, she proposed, based on the usage of the verb נז to describe the movement of Halley's Comet in the Maresha ostraca, that this word is used in the same way in the "Birth of Noah" text (4Q535, Frg. 3). Thus, 4Q535 is probably referring to the horoscope of the "Elect of God" as well, albeit in a very fragmentary context (see Eshel 2011: 183-184). The last example in this category is the reading of another
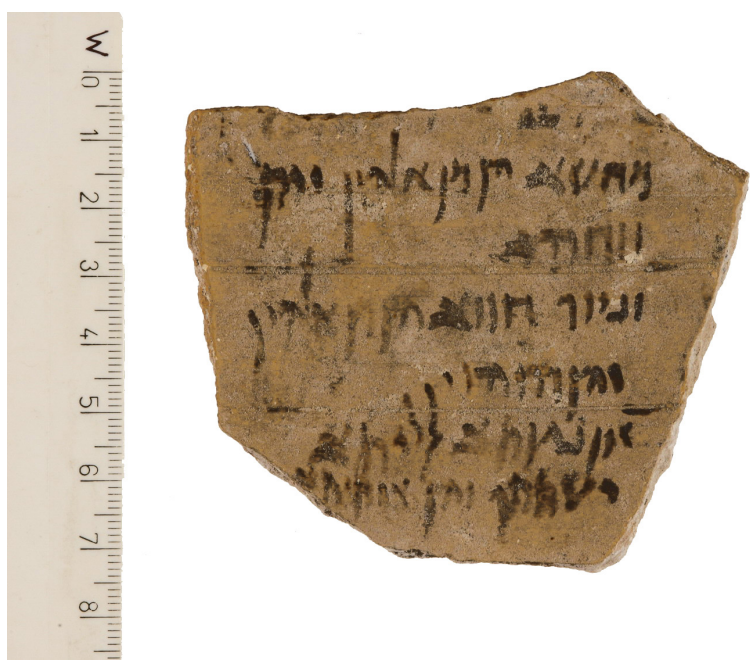

Fig. 12 - Aramaic ostracon with astrological terms ostracon (Reg. No. 169-94-1392-S1): "Should a comet be seen, it is from the gods, and indeed, you see it!" Here we have astrology as a sign from the gods, a well-known phenomenon in the ancient world. The last genre, relates to the law. In this regard, we have some texts that specifically refer to human relationships in general, and between men and women in particular. In some ostraca we find many references to people, in 
various forms - men and women, פנתתא פלימתא and, as well as a young man or a slave, עלימא, עלימתא While the context is often unclear, occasionally the context is known to us in detail. Of those, the most interesting saying, on the obverse side of a large ostracon (Reg. No. 169-94-1481-S1), is the complete sentence: הן מחטף יחטף אנתתא והן מקח, "If (or: should) he elopes with the woman or should he take her (in marriage)". The ostraca from Maresha are mostly fragmentary, difficult to read, or missing large parts but, in some cases, we were lucky to find some clear and complete lines. This is the case in the ostraca mentioned above, "If (or: should) he elopes with the woman or should he take her (in marriage)", immediately followed by הן בקשט ממלל עמה והן לא "If the man speaks with him (or: her) truthfully, and if not?"; either with his wife, or maybe better: with her father, and some lines later it reads: הן באיש על אנתתא, probably a short sentence for: If (something) bad (is said/found) with regards to the woman". This brings to mind the biblical law of Deut

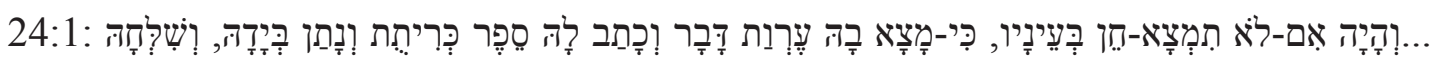

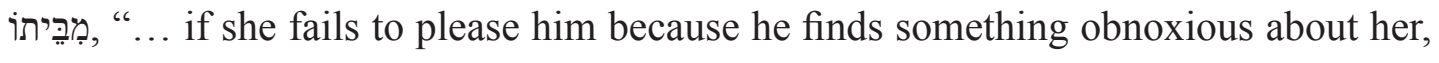
and he writes her a bill of divorcement, hands it to her, and sends her away from his בית שמאי אומרים לא יגרש:9:10 אדם את אשתו אלא אם כן מצא בה דבר ערוה ... ובית הלל אומרים אפילו הקדיחה תבשילו... רבי עקיבא אומר אפילו מצא אחרת נאה הימנה his wife unless he has found unchastity in her... and the school of Hillel says: even if she spoiled a dish for him... and Rabbi Akiva says: even if he found another fairer than she". The first mention of marriage by eloping can be found in the biblical story known as the Outrage of Gibeah (Judges 19-21). After the Battle of Gibeah, the men of Israel swore an oath at Mizpah, saying, "None of us shall give his daughter to Benjamin as a wife". As the story goes, in order to obtain women to enable the survival

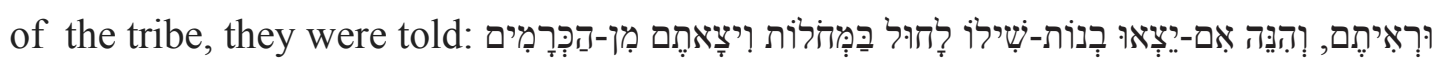

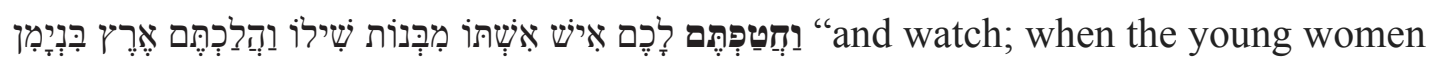
of Shiloh come out to dance in the dances, then come out of the vineyards and each of you carry off a wife for himself from the young women of Shiloh, and go to the land of Benjamin" (Judg 21:21). Marriage by eloping is also described later within the Jewish community. For example in t.Ketubbot 4,9: כשהיו בני אלכסנדריא מקדשין נשים, אחר בא יוזוטפה מן השוק "When the Alexandrians would betroth a woman, afterward someone else would come along and grab her right out of the market". The same custom was also practiced, as noted by Adiel Scemer (2003: 116-117, and notes 43-44 there), by surrounding communities of non-Jews, such as followers of the Nestorian Church.

What we have seen here is that this ostracon might tentatively refer to both marriage 
and divorce. If it refers to marriage then there were two options: taking a wife by eloping or buying her, and if it refers to divorcing her, it was based on the man's criticism of her behavior or appearance.

\section{Conclusion}

In this article we have discussed different genres of texts embedded in common

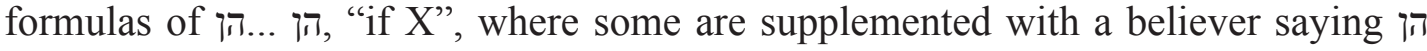
מן אלהין "thus it is from the gods", or: הן מן קוס "thus from (or: caused by) Qōs". Although these texts are varied, one may tie them all to a single shared context, which is the world of divination. We might tentatively associate this type of text, while varied in content, with a 'yes-no question' - perhaps practiced in the divinatory context of a temple, as well attested to in various forms and cultures.

The divination texts, together with the various cultic materials discussed above found in SC 169 and the "Heliodorus Stele" found nearby, may all have been utilized in the shrine (Area 800), also located close by. 


\section{List of References}

Ambar-Armon, E.

2007

Oil Lamps in the Land of Israel during the Hellenistic Period in Light of the Finds from the Maresha Excavations: Conservatism and Tradition alongside Creativity and Innovation. Ph.D. dissertation. Bar-Ilan University (in Hebrew).

Ambar-Armon, E., Kloner, A. and Stern, I. 2010

Oil Lamps on Kernos Vessels from Maresha. Strata: Bulletin of the Anglo-Israel Archaeological Society 28: 103-140.

Bailey, D. M.

1975

A Catalogue of the Lamps in the British Museum, Vol. 1: Greek, Hellenistic and Roman Pottery Lamps. London: British Museum.

1988

A Catalogue of Lamps in the British Museum, Vol. 3: Roman Provincial Lamps, London: British Museum.

Baillet, M.

1982

Qumran Grotte 4:III (4Q482-

4Q520) (DJD VII). Oxford:

Clarendon.
Bartlett, J.R.

1989

Edom and the Edomites. Journal for the Study of the Old Testament Supplements 77. Sheffield: Journal for the Study of the Old Testament Press.

Black, J. George, A. and Postgate, N., eds.

2000

A Concise Dictionary of Akkadian ( $2^{\text {nd }}$ ed.). Wiesbaden: Harrassowitz.

Bliss, F.J. and Macalister, R.A.S.

1902

Excavations in Palestine during the Years 1898-1900. London: Committee of the Palestine Exploration Fund.

Broneer, O.

1930

Corinth Vol. 4, part 2: Terra Cotta Lamps, Cambridge: Harvard University Press.

Cintas, P. 1950

Publications de l'Institut des Hautes Etudes de Tunis, vol. 3: Ceramique punique. Presses universitaires de France. 
Ehrlich, A.

2009

The Art of Hellenistic Palestine.

Oxford: Archaeopress.

Erlich, A. and Kloner, A.

2008

Maresha Excavations Final

Report, vol. 2: Hellenistic Terracotta Figurines from the 1989-1996 Seasons. Israel Antiquities Authority Reports no. 35. Israel Antiquites Authority.

Eshel, E.

2010

Inscriptions in Hebrew, Aramaic and Phoenician Script. Pp. 35-88 in, Maresha III: Epigraphic Finds from the 1989-2000 Seasons. Israel Antiquities Authority Reports no. 45, eds. A. Kloner, E. Eshel, H. Korzakova, and G. Finkielsztejn. Jerusalem: Israel Antiquities Authority.

Aramaic Texts from Qumran in Light of New Epigraphic Finds. Pp. 177-197, in The Dead Sea Scrolls in Context: Integrating the Dead Sea Scrolls in the Study of Ancient Texts, Languages, and Cultures, eds. A. Lange, E. Tov, and M. Weigold. Leiden: Brill.
Eshel, E. Puech, E. and Kloner, A. 2007

Aramaic Scribal Exercises of the Hellenistic Period from Maresha: Bowls A and B. Bulletin of the American Schools of Oriental Research 345: 39-62.

Freedman, S.M.

1998

If a City is Set on a Height, The Akkadian Omen Series Šumma Alu ina Mēle Sakin, vol. I: Tablets 1-21. Occasional Publications of the Samuel Noah Kramer Fund, 17. Philadelphia: University Museum / Babylonian Section.

Gera, D.

2009

Olympiodoros, Heliodoros and the Temples of Koilē Syria and Phoinikē. Zeitschrift für Papyrologie und Epigraphik 169: 125-155.

Graicer. N.

2012

Urban Planning and Building at the City of Maresha in Idumea During the Hellenistic Period. Ph.D. dissertation. Bar Ilan University (in Hebrew). 
Greaves, A.

2012

Divination at Archaic BranchidaiDidyma. Hesperia: The Journal of the American School of Classical Studies at Athens 81: 177-206.

Jones, C.P.

2009

The Inscription from Tel Maresha for Olympiodoros. Zeitschrift für Papyrologie und Epigraphik 171: 100-104.

Kloner, A.

2001

The Economy of Hellenistic Maresha: Inferences based on the city plan and archaeological finds. Pp. 103-131 in Hellenistic Economies, eds. Z.H. Archibald, J. Davis, V. Gabrielsen, and G.J. Olive,. London: Routledge.

2003

Maresha Excavations, vol. 1: Subterranean Complexes 21, 44, 70. Israel Antiquities Authority Reports no. 17. Israel Antiquites Authority.

2011

Maresha Excavations, vol. 3: Epigraphic Finds from the 19892000 Seasons. Israel Antiquities Authority Reports no. 45. Israel Antiquities Authority.
Lemaire, A.

1996

Nouvelles inscriptions arameenes d'Idumee au Musee d'Israel. Paris:

Gabalda.

Luck, G.

1985

Arcana Mundi: Magic and the Occult in the Greek and Roman Worlds: A Collection of Ancient Texts. Baltimore : Johns Hopkins University Press.

McKenzie, J.S. and Reyes, J.A.

2013

Iconographic Programme. Pp. 189229 in The Nabataean Temple at Khirbet et-Tannur, Jordan. Vol. I Architecture and Religion, Final Report on Nelson Glueck's 1937 Excavations, eds. J.S. McKenzie et al., Boston: American Schools of Oriental Research.

Mylonas, G. E.

1961

Eleusis and the Eleusinian Mysteries. Princeton: Princeton University Press.

Perry, L.

Forthcoming

The Faunal Remains of Hellenistic Period Maresha. Ph.D dissertation. Haifa University. (in Hebrew). 
Peters, J.P. and Thiersch, H.

1905

Painted Tombs in the Necropolis of Marissa (Mareshah). Palestine Exploration Fund, vol. 7. London: Committee of the Palestine exploration Fund.

Pollitt, J. J.

1979

Kernoi from the Athenian Agora.

Hesperia 48: 205-233.

Qimron, E.

2013

The Dead Sea Scolls, vol. 3: The Hebrew Writings. Jerusalem: Yad Yizhak Ben-Zvi (in Hebrew).

Rochberg, F.

2010

If $\mathrm{P}$, then $\mathrm{Q}$ : Form and Reasoning in Babylonian Divination. Pp. 19-28 in Divination and Interpretation of Signs in the Ancient World, ed. A. Annus. Oriental Institute Seminars 6. Chicago: The Oriental Institute.

Roebuck, C.

1951

Corinth vol. 14: The Asklepieion and Lerna. Princeton: American School of Classical Studies at Athens.
Rutz, M.

2013

Ancient Magic and Divination, vol. 9: Bodies of Knowledge in Ancient Mesopotamia: TheDiviners of Late Bronze Age Emar and their Tablet Collection. Leiden: Brill.

Schäfer, P. and Shaked, S.

1994

Texts and Studies in Ancient Judaism 42, vol. 1: Magische Texte aus der Kaioer Geniza.Tubingen: Mohr Siebeck.

Schremer, A.

2003

Male and Female He Created Them: Jewish Marriage in the Late Second Temple, Mishnah and Talmud Periods. Jerusalem: The Zalman Shazar Center. (in Hebrew).

Stern, I.

2007

The Population of Persian-period Idumea According to the Ostraca: A Study of Ethnic Boundaries and Ethnogenesis. Pp. 205-238 in Time of Change; Judah and Its Neighbours in the Persian and Early Hellenistic Periods, ed. Y. Levin. London: T\&T Clark. 
2009

Maresha Inscriptions Provide

Context for a Royal Stele in the

Israel Museum. Near Eastern

Archaeology 72: 60-61.

2012

Ethnic Identities and Circumcised Phalli. Strata: Bulletin of the Anglo-Israel Archaeolocial Society 30: 57-87.

Stern, I., ed.

2014

Excavations of the Maresha

Subterranean Complex 57:

The 'Heliodorus' Cave.

British Archaeological Reports.

International Series 2652.

Stern, I. and Alpert, B.

2014

Maresha, Subterranean Complex

169: Preliminary Report. Hadashot

Arkheologiyot 126.

Wacholder, B.Z.

2001

The Omer Polemics in Fragments

3-4: I Ananni Their Author?, Revue

de Qumran 20: 93-108. 